\title{
PROGRAM PEMBERDAYAAN MASYARAKAT BUDIDAYA IKAN CUPANG (BETTA FISH) DALAM MENDORONG PERTUMBUHAN EKONOMI DITENGAH PANDEMI COVID-19
}

\author{
Aditya Surya Nanda ${ }^{1}$, Fitryani ${ }^{2}$ \\ ${ }^{1}$ Universitas Wijaya Putra \\ ${ }^{2}$ Universitas Wijaya Putra \\ ${ }^{3}$ Nama Institusi Penulis Ketiga
}

adityasurya@uwp.ac.id fitryani@uwp.ac.id

\begin{abstract}
Abstrak
waktu peternak ikan cupang (Bettafish) berusaha bangkit dari keterpurukan dan berharap mendapatkan peluang dalam mendorong pertumbuhan usaha. Mitra pemberdayaan masyarakat kami adalah Bapak Dhana yang memiliki latar belakang sebagai peternak ikan cupang. Peternak ikan cupang masih menggunakan cara sederhana dan hanya memasarkan produknya kepada orang-orang sekitar saja, dan belum mampu memperluas pemasaran, padahal bisnis ikan cupang sangat menjanjikan dan dapat memberikan potensi dalam mendorong pertumbuhan ekonomi masyarakat sekitar. Pendampingan personal terhadap mitra dilakukan dengan membuat rencana yang akan dilakukan oleh tim memberikan pelatihan untuk memasarkan produk, memberikan varian baru serta memberikan pendampingan tentang pengelolaan keuangan yang baik dari usaha mereka mulai dari proses pengelolaan produksi, pembukuan sederhana, pemasaran efektif dan inspirasi penegusaha sukses dengan mendatangkan para pakar yang kompeten untuk mendongkrak usaha mereka. Kemudian mendampingi mitra dalam memasarkan produk secara offline dan online agar jangkauan pasar lebih luas. Dengan begitu diharapkan pendapatan dan kesejahteraan mitra akan meningkat.
\end{abstract}

Kata Kunci: Pemberdayaan Masyarakat, Peternakan, Ikan Betta Fish

\section{PENDAHULUAN}

Dampak pandemi Covid-19 terhadap masyarakat Surabaya sangat besar, dari beberapa masyarakat yang kesulitan bahkan kehilangan mata pencahariannya untuk memenuhi kebutuhan hidup sehari-hari, lumpuhnya berbagai akses jalan raya di beberapa kota di provinsi Jawa Timur khususnya
Surabaya yang mengalami Zona Merah (Kirana dkk, 2020). Sementara pertumbuhan ekonomi diperkirakan mengalami penurunan dari 5,4\% menjadi 2,5\%, dan bahkan bisa menjadi minus 0,4\%. Krisis akibat Covid-19 saat ini terjadi secara simultan, sehingga akibatnya sangat dirasakan oleh kelompok rentan yang semakin terpuruk, 
diantaranya kelompok usaha yang membutuhkan keramaian massa, kelompok pekerja harian lepas, pedagang kaki lima, para buruh yang terdampak PHK, petani dan masyarakat miskin (Eddyono dan Suzanna, 2020). Siklus aktivitas ekonomi masyarakat sangat menurun secara drastis, maka pemerintah harus mengambil kebijakan strategis yang akseleratif dalam menangani kesulitan ekonomi yang menimpa masyarakat (Olaniyi, 2020).

Eksternalitas ekonomi dari Covid- 19 yang paling nyata terlihat saat ini adalah fenomena banyaknya karyawan yang dirumahkan. Pemutusan Hubungan Kerja (PHK), dan berbagai perusahaan yang mulai bangkrut. Berdasarkan data Kementerian Ketenagakerjaan (Kemnaker) tahun 2020, total pekerja yang dirumahkan dan kena PHK selama masa pandemi ini telah mencapai 1.943.916 orang dari 114.340 perusahaan.

Situasi semacam ini secara otomatis akan berdampak pada aspek-aspek lain, terutama kepada pekerja harian lepas, pelaku UMKM, usaha rumah makan, dan usaha-usaha masyarakat yang bergantung pada keramaian massa. Situasi ini secara otomatis pula mempengaruhi daya beli masyarakat yang menurun secara signifikan, dimana perputaran uang di tengah masyarakat menjadi sangat minim, pada saat yang sama produksi barang pun sangat terbatas, sehingga terjadi defisit perdagangan dalam siklus perekonomian (Kurniawansyah dkk, 2020).

Berkenaan dengan pandemi virus Corona Covid 19 serta dampaknya terhadap perekonomian nasional, khsuusnya para pelaku usaha sektor mikro kecil dan menengah yang hampir sebagian besar lumpuh dan diambang kebangkrutan. Maka dalam penelitian ini penulis merasa tertarik dan memandang perlu untuk mengkaji beberapa aspek menenai program pemberdayaan masyarakat peternak bettafish dalam mendorong pertumbuhan ekonomi ditengah pandemi covid-19 di Surabaya. Upaya yang dilakukan pemerintah adalah menganggarkan dana ratusan triliun demi menopang industri. Sejumlah insentif dan subsidi disiapkan guna menopang UMKM, dan korporasi swasta agar mampu bertahan menghadapi pandemi Covid-19. Salah satu anggaran digelontorkan untuk penjaminan kredit modal kerja baru guna mendorong pertumbuhan sektor Usaha Mikro Kecil dan Menengah (UKM). Anggaran yang disiapkan untuk melakukan penjaminan tersebut adalah sebesar Rp. 125 triliun.

Poin utama dalam kebijakan distribusi ini adalah diberikan bantuan tunai dan bantuan bahan pokok, sambil melaksanakan program kemitraan dengan berbagai unsur usaha mikro dan makro masyarakat, yaitu diberikannya insentif pada UKKM, usaha-usaha rumahan masyarakat dan pedagang- pedagang kecil. Pemberian bantuan tersebut saat ini adalah langkah yang paling konkrit untuk menguatkan relasi antara pemerintah dengan masyarakat di tengah pandemi Covid-19 ini. Kunci dari penyehatan kembali kondisi ekonomi nasional adalah survival di tingkat individu dan entitas usaha. Oleh karena itu negara harus mengerahkan segenap upaya, termasuk dengan memberikan stimulus, agar rakyatnya tidak collaps semasa krisis, tetap produktif dan memiliki penghasilan memadai, serta bisnis dapat terus berjalan. (Hardiwardoyo, 2020).

UMKM merupakan salah satu bidang usaha yang memiliki peranan cukup penting bagi pertumbuhan ekonomi, selain itu UMKM juga memiliki andil dalam penyerapan tenaga kerja dan distribusi hasil-hasil pembangunan. Dalam sepuluh tahun terakhir, pertumbuhan jumah unit UMKM tahun 2016 - 2019 mengalami peningkatan sebesar 4,2 persen setiap tahunnya dan rata-rata kontribusi UMKM terhadap Produk Domestik Bruto (PDB) Indonesia selama 3 tahun terakhir lebih dari 50 persen. Hal ini membuktikan bahwa UMKM mampu mendongkrak sekotor perekonomian masyarakat secara mandiri dan mendukung laju pertumbuhan pertumbuhan ekonomi di Indonesia Karena itulah UMKM menjadi salah satu sektor usaha yang diunggulkan oleh Bank Indonesia untuk mendorong pertumbuhan ekonomi. Salah satu jenis usaha UMKM di Indonesia yang sedang mengalami trend saat ini adalah usaha peternakan ikan cupang. 
Menurut data kominfo pada tahun 2021 nilai jual ikan cupang mengalami kenaikan yang cukup signifikan yakni sebesar 25\% pertahunnya. Melihat gambaran usaha ini mitra kami sangat tertarik untuk mengembangkan usahanya agar lebih maju dan juga berkembang.

Mitra pemberdayaan kami adalah Bapak Dhana, pengetahuan tentang merawat ikan cupang sudah dipahami dan dipraktikkan oleh beliau selama 2 tahun, dan dilakukan secara otodidak, hanya mengandalkan wawasan dan membaca. Selama sebelum terjadi pandemi Covid-19 iklim usaha Bapak Dhana tergolong biasa saja, tidak ada peningkatan hasil secara signifikan, persaingan di daerahnya masih sangat minim, karena perawatan dan penjualan dilakukan secara offline dari rumah.

Proses perkembangbiakkan ikan cupang Bapak Dhana juga masih tergolong tradisional, dengan menggunakan alat-alat sederhana, yang kapasitasnya tidak dapat dilakukan secara maksimal, sehingga jenis ikan yang diternak hanya ikan cupang jenis avatar dan belum ada varian lain. Perawatan ikan cupang oleh Bapak Dhana tidak diberi perlakuan khusus, namun tetap memperhatikan aturan untuk menjaga ikan cupang tetap dalam kondisi sehat dan baik. Kolam ikan tempat penakaran benih cupang hanya satu dengan bentukan yang tidak telalu luas. Minimnya SDM dan pengetahuan penjualan offline otodidak yang dimiliki mitra serta keluarga juga merupakan alasan lain mitra kami tidak bisa mengembangkan varian ikan cupang lainnya karena khawatir ikan cupangnya tidak laku. Hal inilah yang menjadikan mitra kami tidak menjual jenis varian lain ikan cupang. Wadah yang digunakan untuk meletakkan ikan cupang bisa menggukan plastik toples ataupun dari bahan kaca seperti soliter. Kemudian ikan ditaruh kedalam aquarium dan dibiarkan beradaptasi dengan sekitarnya, sehingga umur hidupnya bisa jauh lebih lama. Karena terbatasan tempat dan juga pengetahuan mitra membuat usaha ikan cupang Bapak Dhana belum mampu menghasilkan banyak varian ikan cupang.
Budidaya ikan cupang memerlukan banyak perawatan, dan seringkali peternak menemui banyak masalah:

1. Jenis ikan cupang yang sangat banyak, menjadi satu permasalahan tersendiri, yakni pselera pasar juga mengalami banyak perbedaan, tiap jenis memilki cara perawatan yang berbeda, dan membutuhkan banyak waktu serta treatment agar benih yang dihasilkan bagus dan sesuai dengan permintaan pasar, oleh sebab itu, menciptakan banyak varian baru juga menjadi salah satu kendala mitra.

2. Harga cupang yang cenderung tidak stabil membuat peternak ikan harus mahir mencari celah tentang patokan keuangan dan strategi penentuan harga jual. Pembukuan yang baik perlu dilakukan untuk mengurangi resiko-resiko kerugian bagi peternak ikan.

3. Karena ikan cupang merupakan golongan ikan hias, pemasarannya juga membutuhkan jaringan yang luas dan tidak dapat dilakukan hanya secara offline atau mengandalkan kenalan saja.

Solusi yang diberikan untuk mengatasi kendalakendala :

1. Ikan cupang adalah hewan yang memiliki banyak jenisa dan varian. Mengembangbiakkan jenis cupang-cupang dalam aneka varian adalah solusi yang tepat, akan tetapi membutuhkan banyak tempat karena membutuhkan satuan toples dan juga kolam yang lebih banyak.

2. Ukuran dan warna sangat menentukan harga ikan cupang, semakin bagus warna dan bentuk akan membuat harga ikan cupang menjadi lebih mahal, oleh karena itu peternak harus mahir menentukan patokan harga jual guna mengurangi resiko-resiko kerugian bagi peternak ikan.

3. Mempelajari IPTEK dan digitalisasi merupakan solusi yang tepat untuk 
meningkatkan relasi dan jaringan yang luas guna membantu pemasaran ikan cupang agar memiliki efektivitas tinggi dalam penjualan.

Ditengah wabah pandemi Covid-19 yang sedang terjadi di Indonesia, banyak dampak yang terjadi terutama yang dialami oleh peternak ikan cupang di daerah Surabaya. Semenjak beberapa daerah di Jawa Timur diberlakukan pembatasan pergerakan orang dan kerumunan sampai adanya sistem karantina parsial menyebabkan banyak pedagang merugi karena pembeli sangat jarang bahkan tak ada. Beberapa pedagang masih mencari peruntungan berjualan meski dengan resiko ditertibkan. Hal itu, dikarena kehidupan peternak ikan cupang di Surabaya sangat bergantung kepada pendapatan harian.

\section{METODE}

Penelitian dilakukan dengan metode kualitatf deskriptif, Peneliti mengamati bagaimana lingkungan sekitar. Tujuan dari dilakukannya pengamatan lingkungan sekitar adalah untuk mencari peluang usaha yang suasanannya nanti dapat berkernbang dengan baik ke depannya. Berdasarkan hasil pengamatan di lingkungan sekitar didapatkan bahwa masyarakat di lingkungan Kupang Krajan Lor adalah daerah padat dan heterogen. Saat malam hari di daerah Kupang Krajan Lor sangat ramai dengan hilir mudik orang lewat dan juga merupakan pusat keramaian kota Surabaya. Hal ini akan sangat mungkin bisa mendorong berkembangnya usaha peternakan ikan hias, terutama usaha budidaya ikan

\section{Rancangan Penelitian}

Metode evaluasi dilaksanakan dengan cara melakukan evaluasi terhadap program yang dilakukan dengan cara mewawancarai konsumen terhadap kualitas, jenis, ukuran dan tren terhadap Ikan yang dibudidayakan.

\section{HASIL DAN PEMBAHASAN}

\section{Gambaran Umum Usaha}

Berdasarkan metode pelaksanaan kegiatan yang dilakukan oleh Tim pengabdian masyarakat tentang pengelolaan manajemen usaha dan mitra budidaya ikan betta fish(ikan cupang) di Kelurahan Kupang Krajan Kota Surabaya yang menjalankan usaha budidaya ikan cupang adalah Bapak Dhana. Awal dari usaha budidaya ikan cupang adalah karena hobi memelihara ikan, namun seiring berkembangnya waktu saat tahun 2019 terjadi pandemic covid-19 yang menjadikan masyarakat tidak keluar rumah dan mereka merasa bosan dan membutuhkan hiburan, kemudian salahsatu pemuas hobi adalah memelihara ikan cupang, ikan tersebut dipilih karena memiliki warna bagus sehingga membuat perasaan senang jika dipelihara karena keindahannya, ukuran yang relative kecil membuat perawatan yang dilakukan tidak membutuhkan biaya banyak jika dibandingkan dengan memelihara ikan pada umumnya. Bapak Dhana melihat peluang dengan maraknya hobi memelihara ikan ini, sehingga Bapak Dhana ikut memlihara dan mempelajari bagaimana sifat dari ikan yang satu ini, dengan berbekal pengalaman Bapak Dhana dibantu support oleh tim pengabdian masyarakat untuk bias mengembangkan bisnis ikan cupang ini dengan baik dan optimal karena hobi adalah kegiatan yang ada siklusnya, maka perlu adanya variasi untuk tetap dapat mendapatkan pangsa pasar, penentuan bibit dan kualitas perlu dilakukan untuk dapat bersaing dengan competitor serupa sehingga dapat menerapkan strategi yang tepat, oleha karena itu program dan strategi peningkatan produk dan pemasaran serta keuangan.

\section{Tahapan Budidaya}

Berdasarkan metode pelaksanaan kegiatan yang dilakukan tim pengabdian masyarakat tentang Tahapan- tahapan yang akan dilakukan adalah sebagai berikut :

1. Untuk masalah di bidang budidaya, tim akan memberikan saran dan uji coba penambahan jenis ikan yang lebih beragam dan diminati masyarakat.

Ekonomi, Sosial dan Budaya 
2. Untuk masalah keuangan, tim akan memberikan Pelatihan dan Pendampingan Pembuatan Pembukuan Sederhana untuk menentukan harga yang akurat dan mengetahui perkembangan usaha mereka.

3. Untuk masalah di bidang pemasaran, tim akan mengawal mereka membuat desain tempat yang modern dan praktis. Lalu mendampingi mereka melalukan pemasaran secara online agar jangkauan pasar mereka lebih luas. Secara online akan dilakukan dengan pembuatan kontak whatsapp dan pemasaran melalui market place. Untuk pemasaran online akan didahului dengan pelatihan dan pendampingan IT yang melibatkan mitra dan keluarga mitra.

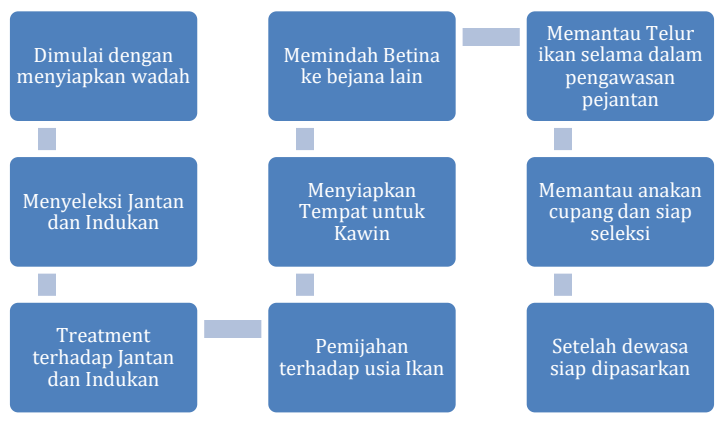

\section{Gambar 1 Tahapan Budidaya Ikan Cupang}

Berdasarkan gambar 1 diatas pemilihan indukan dan jantan adalah salahsatu tahapan utama yang sangat penting, karena bibit yang baik akan mempengaruhi kualitas indukan dan jantan yang berkualitas baik, selanjutnya sebelum mengawinkan ikan cupang dilakukan pemijahan terlebih dahulu agar diketahui bagaimana ciri-ciri ikan cupang yang siap kawin. Ada masa ideal untuk melakukan penjodohan atau mengawinkan ikan cupang yakni sudah berusia 6 bulan keatas dan sebaiknya tidak lebih dari 14 bulan. Permasalahan dalam melakukan penjodohan pada ikan cupang adalah ada beberapa ikan yang stress sehingga tidak bisa dipaksakan untuk dilakukan kawin.

Nutrisi menjadi bagian penting selanjutnya karena makanan yang bernutrisi akan membuat warna ikan cupang menjadi lebih cerah dan menarik, dengan memberikan jentik nyamuk dan cacing darah serta beberapa pellet khusus sehingga dapat memaksimalkan kualitas dari ikan cupang. Dnegan memberikan makanan tersebut kualitas akana menjadi lebih baik dan tentu saja akan mendorong minat pelanggan. Akuarium yang dibutuhkan cukup besar sehingga dapat membuat ikan nyaman dengan penampungan air sebanyak 19 liter atau 1 galon air, jumlah air ini menjadi standar utama dalam membentuk siklus nitrogen, benih ikan sangat rapuh jika tidak ditangani dengan cara baik justru akan membuat kerugian, kondisi air yang selalu bersih dan memisahkan cupang jantan, karena cupang jantan adalah ancaman.Ruangan yang cukup untuk ikan-ikan cupang. tidak perlu menambahkan substrat (media yang digunakan untuk menumbuhkan tanaman, atau tanah di dalam akuarium) karena akan mempersulit pejantan untuk mengambil telur, dan burayak bisa tersangkut di dalamnya.

Biarkan ikan cupang beradaptasi dengan lingkungan barunya selama satu bulan, minimal dua minggu. Selama waktu adaptasi, kamu harus memantau kesehatan mereka, pastikan mereka tidak terjangkit penyakit apapun. Selain itu, sebaiknya berikan ikan cupang mu makanan hidup. Hal ini akan membantu meningkatkan kadar karotenoid pada ikan cupang jantan yang dapat membuatnya tampak sehat dan cerah. Siapkan tangki pembiakan dengan baik. Pastikan tidak ada gangguan apapun di dekat tangki atau dengan tangki ikan apapun atau banyak aktivitas manusia. Ikan cupang sangat menyukai privasi saat kawin. Isi air tangki setinggi 7-10 cm. Ikan yang baru menetas akan kesulitan meraih permukaan untuk bernapas dan makan jika airnya terlalu dalam. Tambahkan filter spons dan juga pompa. Selain Itu jangan lupa untuk menambahkan pemanas, tempatkan pemanas sehingga tidak terendam sepenuhnya. Tambahkan daun almond atau styrofoam ke bagian depan tangki. Selain itu tambahkan juga lumut di dalam tangki. Buatlah tempat untuk bersembunyi para ikan sebanyak mungkin. Tapi jangan terlalu banyak sehingga mereka kesulitan untuk menemukan satu sama lain. 


\section{Pemasaran}

Sebelum dilakukan pendampingan dan pelatihan, penjualan ikan dilakukan cara sederhana, yaitu menjual barang secara langsung kepada masyarakat sekitar dengan ditempatkan pada botol bejana dengan cakupan yang tidak terlalu luas. Setalah dilakukan pelatihan dan pendampingan pemasaran dapat dilakukan dengan skala lebih luas lagi yakni selain menggunakan marketplace sebagai sarana untuk menjual barang secara online dan menggunakan medua social Strategi bauran promosi dapat dilakukan dengan memmanfaatkan empat metode seperti di jelaskan dalam Madura (2007:274) yaitu : iklan, penjualan perorangan(personal selling), promosi penjualan dan hubungan masyarakat (public relation). Iklan merupakan presentasi penjualan yang bersifat non personal di komunikasikan dalam bentuk media dan non media untuk mempengaruhi sebagian besar pelanggan. Personal selling adalah presentasi penjualan perorangan untuk mempengaruhi astu atau lebih pelanggan. Sedangkan promosi penjualan dapat dilakukan dengan memberikan potongan dan sampel produk (Madura, 2007:290)

\section{Keuangan dan Administrasi}

Pengelolaan keuangan adalah bagian penting dalam mencapai tujuan usaha, sebagai UMKM harus mampu menerapkan system keuangan dan memproses transaksi sehingga dapat dijadikan alat dalam mengambil keputusan berdasarkan informasi yang diperoleh. Kelemahan usaha UMKM selama ini adalah system administrasi dan catatan usaha yang masih sangat sederhana sehingga sulit sekali mencapai efektifitas dalam menjalankan kegiatan usahanya dan kurang bersaing. Pada masa awal budidaya pengeloaan budidaya sulit jika bersaing dengan competitor serupa, dengan adanya pelatihan tata kelola administrasi menjadi lebih baik dan data tentan pembelian bibit dan biaya perawatan telah dicatat sehingga harga jual dapat ditentukan dengan baik sesuai varian dan kualitasnya berkisar antara puluhan ribu hingga ratusan ribu, untuk ikan cupang yang sisi warna dan ukuran kurang bagus akan disortir dan dijual dengan harga murah antara $\mathrm{Rp}$ 7000 - Rp 25.000 sedangkan untuk yang berkualitas dan varian bagus mencapai Rp 300.000 per ekor. Harga tersebut ditentukan oleh beberapa komponen dasar terhadap perawatan karena metode ini lebih sederhana.

Problematika yang dihadapi UMKM adalah mengelola administrasi terutama keuangan, karena sebagian besar dari mereka tidak memiliki pemahamn yang cukup tentang tata laksana administrasi dan pembuatan laporan keuangan, dengan adanya pelatihan tentang administrasi dan keuangan cukup meningkatkan pemahaman tentang tata kelola dasar yang sesuai dengan kebutuhan, perkembangan teknologi turut serta mempermudah dalam menyajikan laporan keuangan, terdapat software yang mudah diaplikasikan, metode penentuan harga pokok dan proses pembebanan biaya budidaya selama periode perawatan dengan cara menjual ikan cupang dengan kualitas biasa lebih murah sehingga pelanggan dapat membeli dengan harga yang terjangkau. Dapat diketahui bahwa budidaya dengan manajerial dan pelatihan yang tepat akan mempermudah Bapak Dhana dalam memantau dan mengkalkulasikan kebutuhan meliputi biaya pangan dan pengeluarannya.

\section{SIMPULAN}

Berdasarkan sasaran yang dipilih dalam kegiatan pengabdian masyarakat terdiri dari beberapa capaian diantaranya:

1. Bidang budidaya ikan cupang mengalami perkembangan yang sangat pesat 2 tahun terakhir akibat pandemi covid-19 mengalami permintaan yang sangat signifikan

2. Administrasi dan keuangan menggunakan pembukuan sehingga penentuan biaya dan harga jual dapat dilakukan dengan akurat dan terukur

3. Bidang pemasaran meningkat karena dilakukan dengan berbagai macam cara, diantaranya menjual langsung kepada pelanggan, membuat marketplace dan 
memanfaatkan media social sebagai solusi dalam meningkatkan pangsa pasar

4. Varian dan kualitas budidaya dapat ditingkatkan dengan menambah jenis indukan serta jantan sehingga kualiat lebuh baik jika dibandingkan dengan sebelumnya

\section{DAFTAR PUSTAKA}

Alderton, D. 1983. Caring for Aquarium Fish. London Word Lock Limited, a Pentos Company.

Anonim. 2001. Cetak Cupang Hias Juara. Trubus. No.381. Edisi Agustus. XXXII. Dalam Bonus. 16 hal.

Billard, R. 1992. Reproduction in Rainbow Trout, Dynamic of Gametogenesis, Biology and Preservation of Gametes. Aquaculture, 100 : 263-298. Boyd, C.E. 1981. Water Quality in Warmwater Fish Pond. Auburn University. Agricultural Experiment Station. Alabama.

Chumaidi, S. I., Yunus, Sahlan, R.Utami, A.Priyadi, P.T, Imanto, S.T. Hartati, D. Bastiawan, Z. Jangkaru, dan R. Arifudin. 1990. Petunjuk Teknis Budidaya Pakan Alami. Puslitbangkan, Jakarta.

Lesmana, D.S. dan I. Dermawan. 2001. Budidaya Ikan Hias Air Tawar Populer. Penebar Swadaya. Jakarta P. 26-30. Lingga, P. dan H. Susanto. 1987. Ikan Hias Air Tawar. Penebar Swadaya. Jakarta 236 hal.

Madsen, J.M. 1975. Aquarium Fishes in Color. Mcmillan Publishing Co, Inc. New York. 248 p. Migdalski, E.C. and G.S. Fichter. 1983. The Fresh and Salt Water Fishes of the World. Crown Publishers, Inc. New York. 316 p.
Perkasa, B.E. 2000. Pelihara Cupang di Kolam 3m2 . Trubus No. 364 Edisi Maret. Tahun XXXI. Satyani, D. 2003. Pengaruh Umur Induk Ikan Cupang (Betta splendens Regan) dan Jenis Pakan terhadap Fekunditas dan Produksi Larvanya. Jurnal Penelitian Perikanan Indonesia.9(4): 13-18. encyclopedia. Blandford Press. Dorset. GDR. 285 pp. 